\title{
Interferon- $\gamma$, a valuable surrogate marker of Plasmodium falciparum pre-erythrocytic stages protective immunity
}

\author{
Blanca-Liliana Perlaza', Jean-Pierre Sauzet ${ }^{1}$, Karima Brahimi ${ }^{1}$, Lbachir BenMohamed $^{2}$, Pierre Druilhe ${ }^{1 *}$
}

\begin{abstract}
Immunity against the pre-erythrocytic stages of malaria is the most promising, as it is strong and fully sterilizing. Yet, the underlying immune effectors against the human Plasmodium falciparum pre-erythrocytic stages remain surprisingly poorly known and have been little explored, which in turn prevents any rational vaccine progress. Evidence that has been gathered in vitro and in vivo, in higher primates and in humans, is reviewed here, emphasizing the significant role of IFN- $\gamma$, either as a critical immune mediator or at least as a valuable surrogate marker of protection. One may hope that these results will trigger investigations in volunteers immunized either by optimally irradiated or over-irradiated sporozoites, to quickly delineate better surrogates of protection, which are essential for the development of a successful malaria vaccine.
\end{abstract}

\section{Background}

Immunity to the pre-erythrocytic stages of malaria (i.e. sporozoite and liver stages), which can be best induced following immunization with radiation-attenuated parasites at sporozoite stage, is unusual in many respects [1-3]. Indeed, it is a very strong, fully sterilizing immunity, and this stands in contrast to immunity to other stages of Plasmodium. Since this immunity specifically targets the asymptomatic pre-erythrocytic stage, which precedes the pathogenic blood stages, it can ensure a full prophylaxis suitable for travellers and has, therefore, attracted the vast majority of malaria vaccine funding.

Yet, the immune effectors underlying such a strong pre-erythrocytic immunity, as well as the target sporozoite and liver stage (LS) antigens, remain surprisingly poorly known, at least in the case of Plasmodium falciparum in humans $[4,5]$. Thus, the paradox is that the most promising and effective vaccine against malaria relies on mechanisms which are not identified, nor even searched for. The lack of an immunological basis for protection against $P$. falciparum pre-erythrocytic stages is, in turn, inhibiting any rational progress with the few

\footnotetext{
* Correspondence: druilhe@pasteur.fr

${ }^{1}$ Malaria Vaccine Development Laboratory, Pasteur Institute, 25-28 rue du Dr. Roux, 75724 Paris, Cedex 15, France

Full list of author information is available at the end of the article
}

vaccine candidates under development, and the identification of better candidates [6].

Conversely, over the past 30 years there have been extensive studies conducted using rodent malaria species in laboratory models. These studies have, in a way, added to the confusion by demonstrating a plethora of very effective mechanisms, ranging from sporozoiteneutralizing antibodies to cell-mediated immunity and its various effectors, though without providing a single clue as to which of them would be critical against P. falciparum [7].

The difficulties are related to the diversity of the models employed, their relevance and the strong efficacy of each immune effector investigated in one or the other model [8]. Indeed, numerous studies have demonstrated a role for antibody responses in protection, both under in vitro and under in vivo conditions. In this case, many antibody-mediated mechanisms have been demonstrated including detachment of the sporozoite surface ("circumsporozoite precipitation") [9], opsonization [10], ADCC [11], inhibition of sporozoite invasion and inhibition of intra-hepatic development [12,13]. Conversely, MHC expression by the host cell, the hepatocyte, has understandably led to analysis and description of the potent effects of various T-cell subsets [14-18]. Studies, both in vitro and in vivo, have established by selective depletion [19-22], knock-outs or adoptive transfer 
[16,23-26], the role of mainly CD8 cells but also CD4 T-cells (reviewed in [27]), $\gamma \delta$ T-cells [28], NK [29,30] and NKT-cells [31], or stellate (Ito) cells [32], thought to act either directly (e.g. by a CTL effect) or indirectly either by their mediators or $\mathrm{T}$-cell driven recruitment of inflammatory cells, predominantly polymorphs macrophages and Kuppfer cells. Among the many immune mediators in which a protective effect was reported, the most potent are interleukin 12 (IL12) [33], interferon gamma (IFN- $\gamma$ ) [20,34-36], $\mathrm{O}_{2}$ - [37], and NO radicals, but also, NO synthase [38-40], TNF [41,42], IL1 [35], IL6 [43] leading to the secretion of C-reactive protein [44], hemopexin, $\alpha 1$-anti-trypsin and $\alpha 2$-macroglobulin to name but a few, whose ability to block liver schizogony was reported as being highly effective [45].

The diversity of immune effectors also reflects the diversity of the host-parasite combinations in which they were described. Indeed the combination of each of the rodent Plasmodium with each of the many available inbred mice strains, or the natural host the tree-rat Thamnomys, constitute a plethora of situations, which differ from each other and in which the main effector also differs $[7,46,47]$. A main bottleneck with those models is to determine which of them, if any, is relevant to the human-P. falciparum situation. This essential issue remains unresolved. After over three decades of investigations in animal models, the question: "what would be the most likely protective immune effector and surrogate marker of protection relevant to the human-P. falciparum situation" remains open and unresolved. Results from such models are thus at best indicative, and at worst irrelevant, and therefore can be misleading $[8,46]$. This is demonstrated by the large variety of vaccine formulations that induce those immune-effectors which proved highly effective at protecting rodents, yet failed when evaluated in human clinical trials [48-50].

The immune effectors responsible for protection in humans remain unknown, to the extent of being unable to clarify the simplest dichotomy of whether it is mainly dependant on either "antibody" or on "T-cells", at large (reviewed in $[4,5,51]$ ).

Previous work with P. falciparum irradiated sporozoites, and $P$. falciparum-derived vaccine formulations, particularly liver stage antigen-3 (LSA3) [52], has consistently pointed to IFN- $\gamma$ as a marker associated with protection against $P$. falciparum pre-erythrocytic stage. The present paper reviews the few available in vitro results and more abundant in vivo findings in non-human primate models (according to methods which are described in the references quoted below) that document this matter, and highlight how these findings are consistent with reports in humans.

Given the limitations of the rodent models mentioned above, only observations previously made with
P. falciparum are mentioned, to highlight more clearly than previous reports the critical role of IFN- $\gamma$ as either a critical immune mediator or at least a valuable surrogate marker of protection.

\section{IFN- $\boldsymbol{\gamma}$ : a critical immune mediator and/or surrogate marker of protective immunity against $P$. falciparum pre- erythrocytic stages}

Results supporting a critical role of IFN- $\gamma$ in protective immunity against $P$. falciparum pre-erythrocytic stages come from studies conducted both in vitro and in vivo, in chimpanzee, Aotus and, to some extent, in humans. Data obtained in higher primates are particularly valuable, as several animals underwent multiple challenges. Since all immunized animals were not protected this situation provided an opportunity to compare responses in protected versus non-protected challenges.

\section{IFN- $\gamma$ inhibits $P$. falciparum liver schizogony in vitro}

In vitro studies with $P$. falciparum in primary cultures of human hepatocytes revealed a very potent effect of IFN- $\gamma$. Indeed, very low concentrations of IFN- $\gamma$ were efficient against $P$. falciparum liver forms and moderate concentrations were able to fully block the liver schizogonic development. Concentrations of 1 and $10 \mathrm{IU} / \mathrm{ml}$, achieved respectively 90 and $100 \%$ inhibition of $P$. falciparum liver schizogony [35], and up to $40 \%$ inhibition was still obtained at a concentration as low as $0.1 \mathrm{IU}$. Subsequent studies confirmed the strong effect of IFN- $\gamma$ though with minor differences in the extent of inhibition obtained, possibly related either to the recombinant IFN- $\gamma$ employed, or to experimental conditions. Thereafter, IFN- $\gamma$ has been frequently included as a positive control for in vitro drug or sporozoite inhibition studies and results have reproduced the initial findings (unpublished material).

\section{IFN- $\gamma$ response is associated with protection in Aotus monkeys}

In a preliminary study, sterile protection against P. falciparum sporozoites challenge $\left(10^{5}\right.$ sporozoites IV) was achieved in three out of five monkeys immunized with a microparticulate vaccine formulation of LSA3, without adjuvant [53]. Antibodies reacting with the native parasite sporozoite protein were induced at low titers, but were later boosted following sporozoite challenge. The LSA3-specific IFN- $\gamma$ secretion, measured either by ELISpot or sandwich ELISA assays, was detectable in all LSA3 immunized animals. However, IFN- $\gamma$ responses were significantly higher in protected versus non-protected monkeys (Figure 1).

In a second study, monkeys were immunized using two long LSA3 synthetic peptides formulated in the $\mathrm{ASO}_{2}$ adjuvant [54]. Protection was achieved in all 


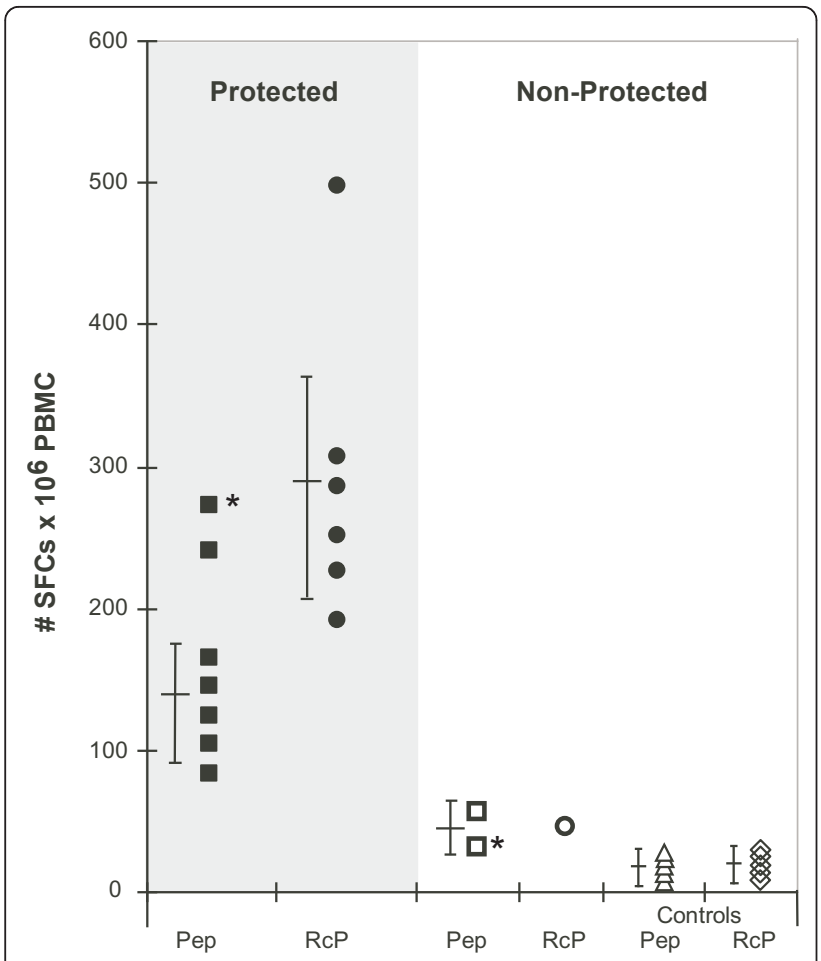

Figure $1 \mathrm{IFN}-\gamma$ is associated with protection induced by LSA3 in Aotus monkeys. Specific IFN- $\gamma$ responses were studied in nine Aotus immunized either by LSA3 recombinant proteins [53] or by long peptides [54]. Monkeys were challenged with P. falciparum sporozoites from Santa lucia strain and the IFN- $\gamma$ responses were evaluated in protected, non-protected and control animals immunized with the GST or ASO2 adjuvant alone. After immunization, the production of IFN- $\gamma$ was assessed either ex-vivo by ELISpot or by ELISA after $40 \mathrm{~h}$ of in vitro re-stimulation with LSA3 peptides (squares) or Rc proteins (circles), as described in detail in [53] and [55].

immunized monkeys challenged with $10^{5}$ P. falciparum sporozoites, in contrast to controls receiving the $\mathrm{ASO}_{2}$ adjuvant alone. Protection in monkeys immunized with either one of the two LSA3 peptides was associated, besides antibody responses, with strong IFN- $\gamma$ secretion specific to the synthetic immunogen as well as to the native protein. Though all animals of the $2^{\text {nd }}$ study were protected, IFN- $\gamma$ secretion was at levels similar to those measured in protected monkeys from the first study (Figure 1).

\section{IFN- $\gamma$ response is associated with protection in chimpanzees}

Three different LSA3 vaccine formulations were assessed in the chimpanzee experimental challenge model. A first group was immunized using a vaccine formulation consisting of LSA3 recombinant proteins delivered in $\mathrm{ASO}_{2}$ adjuvant [55]. The antibody responses to different regions of the protein were homogeneously high among both protected and non-protected animals, providing no predictive indication of protection. In contrast, IFN- $\gamma$ production was markedly higher in the protected chimpanzees (Cyndi and Wendy) compared to non-protected chimpanzees (Marti and Willy) (Figure 2). This was true when considering responses from lymphocytes challenged in vitro by either LSA3 recombinant antigens or by synthetic peptides (Figure 2).

A second group of chimpanzees was immunized with a vaccine formulation consisting of two LSA3 lipopeptides, delivered in adjuvant-free saline, and a third LSA3 peptide mixed with montanide adjuvant [55]. Very strong B and T-helper cell responses were observed, and all peptides induced the secretion of IFN- $\gamma$, with the highest responses directed to the peptide from the non-repeated $\mathrm{N}$-terminal region. Consistent with results obtained in Aotus monkeys, markedly higher IFN- $\gamma$ levels were observed among chimpanzees showing protection upon challenge (Gerda, Dirk, Mopia, Mgbado), as compared to unprotected animals (Iris, Karlien). The above pattern of immune responses investigated before challenge correlated with protection observed in two successive $P$. falciparum sporozoite challenges performed at either moderate or very high sporozoites challenge dose $(20,000$ and 1 million sporozoites respectively).
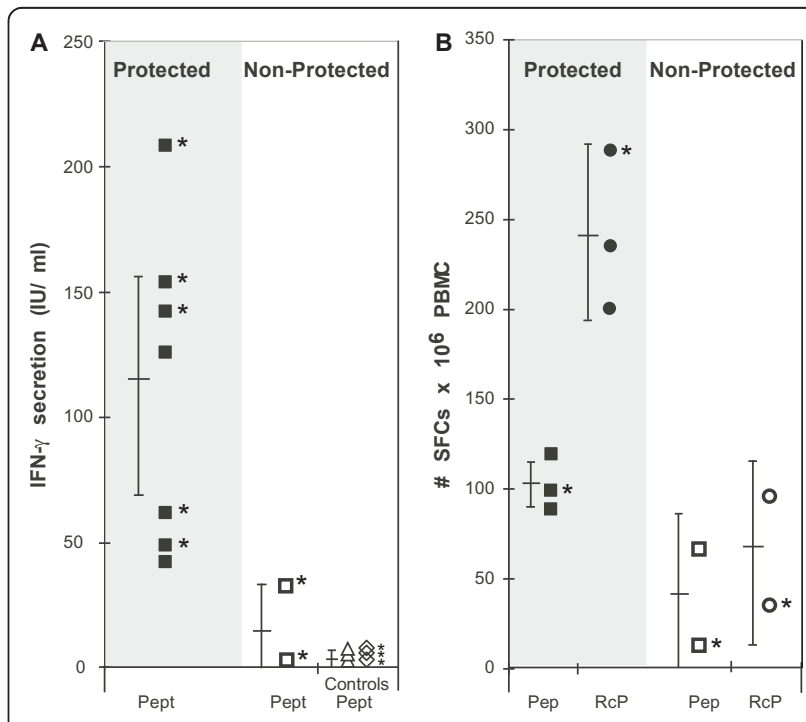

Figure 2 IFN- $\gamma$ is associated with protection induced by LSA3 in chimpanzees. Summary of specific IFN- $\gamma$ responses in eighteen chimpanzees immunized either by LSA3 recombinant proteins or by Peptides/Lipopeptides. Chimpanzees were challenged once or twice $\left.{ }^{*}\right)$ with $P$. falciparum sporozoites. After immunization, the IFN- $\gamma$ producing $T$ cell responses were compared in protected versus nonprotected animals. Chimpanzees that received adjuvant alone or saline alone (vehicle) were used as controls. The production of IFN- $\gamma$ was assessed after in vitro stimulation with LSA3 peptides (squares) or Rc proteins (circles) using either ELISA (A), as described [55] or exvivo ELISpot (B) as described [53,56]. 
Because the high degree of protection obtained above following LSA3 immunization was not obtained in all animals, it was hypothesized that combination of LSA3 with other pre-erythrocytic stage antigens may act synergistically to result in higher levels of IFN- $\gamma$ and better protection. Thus, in a subsequent experiment in a third group of chimpanzees LSA3 was delivered in combination with either LSA1, SALSA or STARP. Surprisingly, the combined immunization led to over three-fold decrease in LSA3-specific IFN- $\gamma$ responses. Indeed, LSA3 alone yielded a mean IFN- $\gamma$ response of $108 \pm 35$ $\mathrm{IU} / \mathrm{ml}$, whereas the LSA3-specific IFN- $\gamma$ secretion obtained with the antigen combinations was markedly lower, either with LSA1 (35 \pm 21 IU), STARP $(16 \pm 4$ IU) or SALSA ( $2 \pm 0,2 \mathrm{IU})$. This was associated with an absence of protection as compared to animals receiving LSA3 alone (Thomas A, Millet P et al, unpublished material). Hence, here again a relationship was observed between the intensity of IFN- $\gamma$ response and protection. These results also suggested a negative interaction between antigens, which is noteworthy at a time when indiscriminate antigen combinations are actively promoted.

The difference in IFN- $\gamma$ levels between protected and non-protected chimpanzees was analysed by a nonparametric median comparison test. The results showed that IFN- $\gamma$ secretion was significantly higher among protected chimpanzees $(\mathrm{p}=0.003)$. When post-immunization, pre-challenge, IFN- $\gamma$ responses were analysed with respect to the outcome of all challenges performed in those animals (as some underwent several successive challenges), the correlation between IFN- $\gamma$ and protection was also significant $(\mathrm{p}=0.0002)$. Conversely, the antibody levels induced in chimpanzee using different immunization protocols were not found to be associated with protection $(\mathrm{p}=0.3)$.

A fourth group of chimpanzees underwent genetic immunization using P. falciparum LSA3-DNA [56]. Protection upon challenge was obtained in four out of six immunized animals, and was reproducible upon a $2^{\text {nd }}$ challenge performed five months later. Immune responses induced by DNA vectors were as scarce in chimpanzees as they were in humans, thereby stressing the homology between these two closely related species. For instance, specific antibodies were not detectable. Conversely, positive IFN- $\gamma$ Elispot responses were obtained in each of the LSA3-DNA immunized chimpanzees, and IFN- $\gamma$ responses to several peptides was associated with protection, i.e. present in protected animals, and absent in immunized-non-protected ones [56].

In the above studies, responses in chimpanzees were specific to LSA-3 and were composed of both MHC class-I and Class-II restricted T cell responses [55-57]. In liver biopsies, the liver schizonts from immunized chimpanzees were surrounded by a large granuloma containing macrophages, lymphocytes, granulocytes able to release around the parasite, very high local concentrations of IFN- $\gamma$, and likely IFN- $\alpha$ [47].

\section{Indications for the role of IFN- $\gamma$ in pre-erythrocytic immunity in humans}

Surprisingly, only indirect and fragmentary indications of the role of IFN- $\gamma$ in malaria pre-erythrocytic immunity have been gathered in humans. A first observation is that attenuated P. falciparum sporozoites as well as subunit vaccines elicit IFN- $\gamma$-producing CD4+ and CD8+ $\mathrm{T}$ cells (reviewed in $[51,58]$ ). The production of IFN- $\gamma$ by LSA3 specific $\mathrm{T}$ cells was observed in each of three volunteers who were protected following immunization with irradiated sporozoites. However, in contrast with the chimpanzee model, no negative control, similarly immunized but non-protected, is available to assess the predictive value of those IFN- $\gamma$ responses. More recently, volunteers could be protected by exposure to nonirradiated sporozoites under chloroquine treatment. Strong IFN- $\gamma$-producing T cells were observed in all immunized volunteers, whereas antibody responses were inconsistent, supporting the potential role of IFN- $\gamma$ producing $\mathrm{T}$ cells in $P$. falciparum pre-erythrocytic immunity [59]. However, the lack of a control group, similarly immunized, but not protected, prevented the establishment of any causal relationship between the levels of IFN- $\gamma$ and the observed protection here also.

Correlations of P. falciparum antigen specific CD4+ $\mathrm{T}$-cell responses with resistance to malaria in humans have been reported [4]. In studies with CS protein and ME-TRAP vectored vaccines, which induced partial protection (ie. a patency delay) antibody levels induced by this regime were low or absent and were not associated with protection (reviewed in [49]). However, using ex vivo and cultured IFN- $\gamma$ ELISPOT assays, which measure mainly effector and central memory $\mathrm{T}$ cells respectively, only the latter showed an association with protection [60,61]. Surrogates were also searched for among the various cohorts immunized by RTSS, showing transient protection. One study identified among individuals without blood parasites for 100 days, a significantly higher frequency of individuals secreting IFN$\gamma$ in response to a CS peptide, than of non-responding individuals [62], whereas several other studies found a correlation with antibody responses (reviewed in [4]).

In malaria endemic areas, populations are exposed to a large variety of other infections, particularly of viral origin. It was reasoned that viral infections could induce substantial levels of IFN- $\gamma$ and this situation could be used as a clue to address the role of IFN- $\gamma$ on the hepatic cycle in vivo in humans. Indeed, a first study showed high serum levels of IFN- $\gamma$, since among 106 individuals 
tested the mean serum concentration was as high as $70 \mathrm{IU} / \mathrm{ml}$ [63]. This subsequently led to the conduction of two immuno-epidemiological studies. The first described a significant correlation between pre-existing serum IFN- $\gamma$ levels and susceptibility to new malaria blood infections, i.e. the successful transhepatic passage of the parasite [64]. In the second, a very significant difference in time to first infection, i.e. protection, was also observed depending on the ability of patient's lymphocytes to secrete IFN- $\gamma$ in response to LSA1 antigen [65]. Both observations document the influence of IFN- $\gamma$ upon the success of exposure to sporozoites in humans. Additional indirect evidence for $\mathrm{CD} 8+\mathrm{T}$ cell derived IFN- $\gamma$ comes from the association of the HLA-Bw53 allele with protection [66] as well as class I restricted responses to the LSA3 and PfExp-1 antigens [67]. However, these indications were not confirmed in another location, nor by a parasitological re-assessment of the initial finding [68].

\section{Discussion}

Results gathered in primates challenged by $P$. falciparum and, to some extent, in humans, point to interferon- $\gamma$ as a possible immune mediator or at least a surrogate marker significantly associated with protection against P. falciparum and actually, the only surrogate available to-date.

Despite the high genetic similarity (up to 99.4\%) between chimpanzee and humans, the remaining differences limit the scope of these results obtained in these higher primates, with only indirect indications that the same holds true in humans. A second limitation is that most of the results concern immunity induced by LSA3, even though there are indications that the same holds true for humans immunized by irradiated sporozoites, or by other preerythrocytic antigen vaccine candidates. Thus data obtained in primates point clearly to IFN- $\gamma$ as a reliable surrogate of protection, whereas data obtained in humans, in the field or in vaccine trials, is in-keeping with this conclusion, however without demonstrating it as clearly $[4,58]$.

It is extremely striking and shocking that the most critical data, which could have been acquired in human volunteers immunized by irradiated sporozoites, is lacking. This is most regrettable, and surprising, considering the massive amounts of funding devoted to pre-erythrocytic vaccines at large. It does not seem reasonable to continue to evaluate the potential of a large number of vaccine formulations in lengthy and costly phase I and phase II field trials, while the identification of immune effectors or a reliable surrogate marker of protection associated with protection against $P$. falciparum pre-erythrocytic stages is close at hand, yet is not searched for.

Indeed, the opportunity exists for a rational approach in the development of malaria pre-erythrocytic stage vaccines by the identification of the relevant mechanism (s) of protection through clinical experiments with irradiated sporozoite immunization. Complete protection is achieved by vaccination with optimally irradiated sporozoites (15-18 kRad), whereas vaccination with overirradiated sporozoites (23-30 kRad) induces strong immune responses but no protection [69]. This constitutes a very discriminative situation best fitted to identify either the critical mechanisms involved, or a surrogate marker of protection (such as a certain level of IFN- $\gamma$ ).

There have been to-date more than 1400 volunteers challenged by $P$. falciparum to assess in humans experimental vaccines that were designed in models [70], the majority of which failed to induce protection. In contrast, there have been less than two dozen volunteers immunized by irradiated sporozoites [69]. Arguably the available and unique irradiated sporozoite model has remained largely underexploited for the last two decades, and disconcertingly it still does not seem to attract much interest. Despite the very high failure rate of clinical trials, the current vaccine development strategy continues, by and large, in an empirical manner.

Studies with $P$. falciparum in primates do not bring much support to the role of antibody (Abs) responses in protection against malaria pre-erythrocytic stages, in contrast to what was suggested by numerous experimental studies and which was emphasized in many reviews. The antibody-mediated detachment of the sporozoite surface (circumsporozoite precipitation) and antibody titration in rodents have been considered for a long time as evidence for a major, if not sole, role of antibodies in protection [9]. Further work conducted in vitro in primary hepatocyte cultures has indicated a strong sporozoite-invasion inhibitory effect by antibodies both for rodent and for human malaria. This was shown to be true for Abs specific to a wide range of antigens such as CS [71,72], STARP [73], LSA3 [74], SALSA (Pasqueto, V. and Druilhe, P. unpublished data), TRAP [75], AMA-1 [76] as well as when using African adults sera which contain a wide range of antibody specificities [13]. Sporozoite invasion inhibition was also confirmed by in vivo passive transfer experiments $[77,78]$. In addition it was also shown that Abs could promote the opsonization of sporozoites by macrophages [10]. Yet, despite the wide range of evidences in various models, results from $P$. falciparum challenges do not bring support for a critical role of Abs as an effector or a surrogate.

In contrast, for IFN- $\gamma$, data gathered using rodent Plasmodium species, despite the limitations of models and the diversity of protective mechanisms involved, are nonetheless in keeping with data obtained with $P$. falciparum. The strong effect of IFN- $\gamma$ upon liver schizogony was documented in all rodent plasmodia 
species employed (Plasmodium berghei, Plasmodium yoelii, Plasmodium chabaudi and Plasmodium vinckei) in various strains of mice $[20,27,34,36,79]$. The studies conducted in models stressed the effect of each component of the cascade going from IL12 to nitric oxyde. Indeed the potent effect of IL12 [33] is logical as it leads nonT and nonB cells to secrete IFN- $\gamma$. The role of IFN- $\gamma$ itself is the most documented by numerous independent studies $[20,34,35]$, including using IFN- $\gamma$ receptor knockout animals, which failed to be protected by irradiated sporozoites [36]. The involvement of NO synthase, downstream of the IFN- $\gamma$ signalling, has been well documented, as well as the direct effect of NOradicals $[33,38,79,80]$. Thus studies with rodent species led to dissect this pathway as essential in defence against malaria liver stage (LS), regardless of the target species used.

Observations in situ showing a large granuloma around $P$. falciparum liver schizonts in protected chimpanzees [47] have also been analysed and modellized in mice [80]. In those experiments, intra-portal delivery of microparticles coated with $P$. falciparum liver stage peptide epitopes induced strong local cellular infiltrates. This intra-hepatic cellular response detected in mice around the parasite's epitope coated microparticles closely mimics the granuloma detected around chimpanzees' liver schizonts. These immune infiltrates were made up of PMN, MO, dendritic cells, but most importantly of IFN- $\gamma$ producing activated $\mathrm{CD} 4+$ and to a lesser extent CD8+ T-cells, suggesting a Th1 type local immune response [80]. Using different schemes of immunization, the size of intra-hepatic cellular infiltrate was recently found to correlate with the level of protection (Perlaza et al, unpublished data). Indeed, immunization schemes that induced better protective immunity were associated with the strongest local IFN- $\gamma$-producing $\mathrm{T}$ cell responses. In addition, kinetic studies indicated that, following PMN recruitment, CD4+ T-cells are the first to migrate into the liver toward the parasite antigens. Although in humans the situation is less clear, several indications point more to Th1 CD4+ cells, rather than $\mathrm{CD} 8+\mathrm{T}$ cells, as the most critical cell type involved in IFN- $\gamma$ secretion [49]. Production of IFN- $\gamma$ by PBMC in response to liver stage antigens was also associated with resistance to re-infection with $P$. falciparum in young African children [65]. Vaccine formulations, such as microparticles and lipopeptides, delivered without adjuvant, which proved protective in non-human primates, also induced mainly type- $1 \mathrm{CD} 4+\mathrm{T}$ cell (Th1) responses but only a low level of CD8 $+\mathrm{T}$ cells responses. Finally, in mice, it was previously found that adoptive transfer of parasite-epitope specific Th1 clones, but not Th2 clones, protected mice against a sporozoite challenge [65].
Hence, the combination of data, from both humans and non-human primates, support that protective immunity against $P$. falciparum liver stages is associated with induction of local intra-hepatic helper-type $1 \mathrm{CD} 4+$ $\mathrm{T}$ cells that secrete high levels IFN- $\gamma$. This suggests that a successful malaria vaccine strategy and formulation should, therefore, promote the induction of strong IFN$\gamma$-producing $\mathrm{CD} 4+$ cell responses.

\section{Conclusions}

In conclusion, it was thought to be useful to report these data, whatever their limitations, at least as an incentive to trigger the implementation of further similar investigations in human beings the absence of which is most surprising and appears to be a missed opportunity. Undoubtedly, if there was a protocol able to induce sterile protection against, for instance, HIV infection in humans, as there is with irradiated sporozoites in malaria, this would probably be immediately exploited to analyse the mechanisms and antigens involved. Why this has not and is still not implemented for the pre-erythrocytic stages of malaria remains a mystery. It would seem that limited clinical trials in relatively small groups of volunteers immunized either by optimally irradiated or over-irradiated sporozoites could help delineate surrogate markers of protection, and thereby contribute to the development of a powerful rationale, which is fundamentally required for the development of a successful pre-erythrocytic stage vaccine, and which is currently lacking.

\section{List of abbreviations}

Abs: Antibody; AMA1: Apical Membrane Antigen 1; CS: CircumSporozoite; LS: Liver Stage; LSA1: Liver Stage Antigen 1; LSA3: Liver Sage Antigen 3; Pf Exp1: Plasmodium falciparum Export 1; SALSA: Sporozoite and Liver Stage Antigen; STARP: Sporozoite Threonine and Asparagine Rich Protein; Th1: T-helper class 1; TRAP: Thrombospondin Related Anonymous Protein.

\section{Acknowledgements}

We are indebted to all participants in the above mentioned studies, particularly Socrates and Myriam Herrera in Cali, Colombia, Pascal Millet, Adrian Luty and collaborators in Franceville, Gabon, Alan Thomas and collaborators at BPRC in Holland, with whom the Aotus and chimpanzee models of $P$. falciparum challenge were developed. These studies were supported by a European INCO-DEV network: "Selection of P. falciparum antigens for MPES vaccine development ", Contract N N ERB IC 15 CT 98037.

\section{Author details}

Malaria Vaccine Development Laboratory, Pasteur Institute, 25-28 rue du Dr. Roux, 75724 Paris, Cedex 15, France. ${ }^{2}$ Laboratory of Cellular and Molecular Immunology, University of California Irvine, College of Medicine, Irvine, CA 92697-4375, USA.

\section{Authors' contributions}

All authors contributed significantly to the writing of the manuscript. All authors read and approved the final manuscript.

\section{Competing interests statement}

The authors declare that they have no competing interests.

Received: 24 August 2010 Accepted: 8 February 2011 Published: 8 February 2011 


\section{References}

1. Clyde DF, McCarthy VC, Miller RM, Hornick RB: Specificity of protection of man immunized against sporozoite-induced falciparum malaria. Am Med Sci 1973, 266:398-403.

2. Clyde DF, Most H, McCarthy VC, Vanderberg JP: Immunization of man against sporozite-induced falciparum malaria. Am J Med Sci 1973, 266:169-177

3. Nussenzweig RS, Vanderberg J, Most H, Orton C: Protective immunity produced by the injection of $\mathrm{x}$-irradiated sporozoites of Plasmodium berghei. Nature 1967, 216:160-162.

4. Hill AV: Pre-erythrocytic malaria vaccines: towards greater efficacy. Nat Rev Immunol 2006, 6:21-32

5. Marsh K, Kinyanjui S: Immune effector mechanisms in malaria. Parasite Immunol 2006, 28:51-60.

6. Druilhe P, Barnwell JW: Pre-erythrocytic stage malaria vaccines: time for a change in path. Curr Opin Microbiol 2007, 10:371-378.

7. Doolan DL, Hoffman SL: The complexity of protective immunity against liver-stage malaria. J Immunol 2000, 165:1453-1462.

8. Chatterjee S, Perignon JL, Van Marck E, Druilhe P: How reliable are models for malaria vaccine development? Lessons from irradiated sporozoite immunizations. J Postgrad Med 2006, 52:321-324

9. Vanderberg J, Nussenzweig R, Most H: Protective immunity produced by the injection of x-irradiated sporozoites of Plasmodium berghei. V. In vitro effects of immune serum on sporozoites. Mil Med 1969, 134:1183-1190.

10. Schwenk R, Asher LV, Chalom I, Lanar D, Sun P, White K, Keil D, Kester KE, Stoute J, Heppner DG, Krzych U: Opsonization by antigen-specific antibodies as a mechanism of protective immunity induced by Plasmodium falciparum circumsporozoite protein-based vaccine. Parasite Immunol 2003, 25:17-25.

11. Mazier D, Renia L, Nussler A, Pied S, Marussig M, Goma J, Grillot D, Miltgen F, Drapier JC, Corradin G, Del Giudice G, Grau GE: Hepatic phase of malaria is the target of cellular mechanisms induced by the previous and the subsequent stages. A crucial role for liver nonparenchymal cells. Immunol Lett 1990, 25:65-70.

12. Hollingdale MR, Nardin EH, Tharavanij S, Schwartz AL, Nussenzweig RS: Inhibition of entry of Plasmodium falciparum and $P$. vivax sporozoites into cultured cells; an in vitro assay of protective antibodies. J Immunol 1984, 132:909-913.

13. Mellouk S, Berbiguier N, Druilhe P, Sedegah M, Galey B, Yuan L, Leef M, Charoenvit Y, Paul C, Hoffman S, Beaudoin RL: Evaluation of an in vitro assay aimed at measuring protective antibodies against sporozoites. Bull World Health Organ 1990, 68:52-59.

14. Bonelo A, Valmori D, Triponez F, Tiercy JM, Mentha G, Oberholzer J, Champagne P, Romero JF, Esposito F, Nebie I, Barbey C, Romero P, Herrera S, Corradin G, Lopez JA: Generation and characterization of malaria-specific human CD8(+) lymphocyte clones: effect of natural polymorphism on $\mathrm{T}$ cell recognition and endogenous cognate antigen presentationby liver cells. Eur J Immunol 2000, 30:3079-3088.

15. Bongfen SE, Torgler R, Romero JF, Renia L, Corradin G: Plasmodium berghei-infected primary hepatocytes process and present the circumsporozoite protein to specific CD8+ T cells in vitro. J Immunol 2007, 178:7054-7063

16. Renia L, Grillot D, Marussig M, Corradin G, Miltgen F, Lambert PH, Mazier D, Del Giudice G: Effector functions of circumsporozoite peptide-primed CD4+ T cell clones against Plasmodium yoelii liver stages. J Immunol 1993, 150:1471-1478.

17. Tsuji M, Romero P, Nussenzweig R, Zavala F: CD4+ cytolytic T cell clone confers protection against murine malaria. J Exp Med 1990 172:1353-1357

18. Weiss WR, Mellouk S, Houghten RA, Sedegah M, Kumar S, Good MF, Berzofsky JA, Miller LH, Hoffman SL: Cytotoxic T cells recognize a peptide from the circumsporozoite protein on malaria-infected hepatocytes. J Exp Med 1990, 171:763-773.

19. Rodrigues M, Nussenzweig RS, Zavala F: The relative contribution of antibodies, CD4+ and CD8+ T cells to sporozoite-induced protection against malaria. Immunology 1993, 80:1-5.

20. Schofield L, Ferreira A, Altszuler R, Nussenzweig V, Nussenzweig RS: Interferon-gamma inhibits the intrahepatocytic development of malaria parasites in vitro. J Immunol 1987, 139:2020-2025.
21. Weiss WR, Sedegah M, Beaudoin RL, Miller LH, Good MF: CD8+ T cells (cytotoxic/suppressors) are required for protection in mice immunized with malaria sporozoites. Proc Natl Acad Sci USA 1988 85:573-576

22. Weiss WR, Sedegah M, Berzofsky JA, Hoffman SL: The role of CD4+ T cells in immunity to malaria sporozoites. J Immunol 1993, 151:2690-2698

23. Khusmith S, Charoenvit Y, Kumar S, Sedegah M, Beaudoin RL, Hoffman SL: Protection against malaria by vaccination with sporozoite surface protein 2 plus CS protein. Science 1991, 252:715-718.

24. Rodrigues MM, Cordey AS, Arreaza G, Corradin G, Romero P, Maryanski JL, Nussenzweig RS, Zavala F: CD8+ cytolytic T cell clones derived against the Plasmodium yoelii circumsporozoite protein protect against malaria. Int Immunol 1991, 3:579-585.

25. Romero P, Maryanski JL, Corradin G, Nussenzweig RS, Nussenzweig V, Zavala F: Cloned cytotoxic T cells recognize an epitope in the circumsporozoite protein and protect against malaria. Nature 1989, 341:323-326.

26. Takita-Sonoda Y, Tsuji M, Kamboj K, Nussenzweig RS, Clavijo P, Zavala F: Plasmodium yoelii: peptide immunization induces protective CD4+ T cells against a previously unrecognized cryptic epitope of the circumsporozoite protein. Exp Parasitol 1996, 84:223-230.

27. Tsuji M: A retrospective evaluation of the role of $\mathrm{T}$ cells in the development of malaria vaccine. Exp Parasitol 2009, 126:421-425.

28. Tsuji M, Mombaerts P, Lefrancois L, Nussenzweig RS, Zavala F, Tonegawa S: Gamma delta $T$ cells contribute to immunity against the liver stages of malaria in alpha beta T-cell-deficient mice. Proc Natl Acad Sci USA 1994, 91:345-349.

29. Doolan DL, Hoffman SL: IL-12 and NK cells are required for antigenspecific adaptive immunity against malaria initiated by CD8+ T cells in the Plasmodium yoelii model. J Immunol 1999, 163:884-892.

30. Roland J, Soulard V, Sellier C, Drapier AM, Di Santo JP, Cazenave PA, Pied S: NK cell responses to Plasmodium infection and control of intrahepatic parasite development. J Immuno/ 2006, 177:1229-1239.

31. Pied S, Roland J, Louise A, Voegtle D, Soulard V, Mazier D, Cazenave PA: Liver CD4-CD8- NK1.1+ TCR alpha beta intermediate cells increase during experimental malaria infection and are able to exhibit inhibitory activity against the parasite liver stage in vitro. J Immunol 2000, 164:1463-1469.

32. Winau F, Quack C, Darmoise A, Kaufmann SH: Starring stellate cells in liver immunology. Curr Opin Immunol 2008, 20:68-74.

33. Sedegah M, Finkelman F, Hoffman SL: Interleukin 12 induction of interferon gamma-dependent protection against malaria. Proc Natl Acad Sci USA 1994, 91:10700-10702

34. Ferreira A, Schofield L, Enea V, Schellekens H, van der Meide P, Collins W, Nussenzweig R, Nussenzweig $V$ : Inhibition of development of exoerythrocytic forms of malaria parasites by gamma-interferon. Science 1986, 232:881-884.

35. Mellouk S, Maheshwari RK, Rhodes-Feuillette A, Beaudoin RL, Berbiguier N,

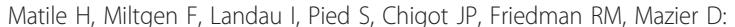
Inhibitory activity of interferons and interleukin 1 on the development of Plasmodium falciparum in human hepatocyte cultures. J Immunol 1987, 139:4192-4195.

36. Tsuji M, Miyahira Y, Nussenzweig RS, Aguet M, Reichel M, Zavala F: Development of antimalaria immunity in mice lacking IFN-gamma receptor. J Immunol 1995, 154:5338-5344.

37. Allison AC, Eugui EM: The role of cell-mediated immune responses in resistance to malaria, with special reference to oxidant stress. Annu Rev Immunol 1983, 1:361-392

38. Mellouk S, Hoffman SL, Liu ZZ, de la Vega P, Billiar TR, Nussler AK: Nitric oxide-mediated antiplasmodial activity in human and murine hepatocytes induced by gamma interferon and the parasite itself: enhancement by exogenous tetrahydrobiopterin. Infect Immun 1994, 62:4043-4046.

39. Nussler AK, Renia L, Pasquetto V, Miltgen F, Matile H, Mazier D: In vivo induction of the nitric oxide pathway in hepatocytes after injection with irradiated malaria sporozoites, malaria blood parasites or adjuvants. Eur $J$ Immunol 1993, 23:882-887.

40. Seguin MC, Klotz FW, Schneider I, Weir JP, Goodbary M, Slayter M, Raney JJ, Aniagolu JU, Green SJ: Induction of nitric oxide synthase protects against malaria in mice exposed to irradiated Plasmodium berghei infected mosquitoes: involvement of interferon gamma and CD8+ T cells. J Exp Med 1994, 180:353-358. 
41. Korner $H$, McMorran $B$, Schluter D, Fromm P: The role of TNF in parasitic diseases: still more questions than answers. Int J Parasitol 2010, 40:879-888.

42. Nussler A, Drapier JC, Renia L, Pied S, Miltgen F, Gentilini M, Mazier D: Larginine-dependent destruction of intrahepatic malaria parasites in response to tumor necrosis factor and/or interleukin 6 stimulation. Eur J Immunol 1991, 21:227-230.

43. Pied S, Renia L, Nussler A, Miltgen F, Mazier D: Inhibitory activity of IL-6 on malaria hepatic stages. Parasite Immunol 1991, 13:211-217.

44. Pied S, Nussler A, Pontent M, Miltgen F, Matile H, Lambert PH, Mazier D: Creactive protein protects against preerythrocytic stages of malaria. Infect Immun 1989, 57:278-282

45. Pied S, Tabone MD, Chatellier G, Marussig M, Jardel C, Nosten F, Mazier D: Non specific resistance against malaria pre-erythrocytic stages: involvement of acute phase proteins. Parasite 1995, 2:263-268.

46. Druilhe $P$, Hagan $P$, Rook GA: The importance of models of infection in the study of disease resistance. Trends Microbiol 2002, 10(10 Suppl):S38-46.

47. Druilhe P, Rénia L, Fidock D: Immunity to liver stages. In Malaria: Parasite biology, pathogenesis and protection. Edited by: Sherman I. Washington DC.: AMS Press; 1998:513-543.

48. Epstein JE, Giersing B, Mullen G, Moorthy V, Richie TL: Malaria vaccines: are we getting closer? Curr Opin Mol Ther 2007, 9:12-24.

49. Hill AV, Reyes-Sandoval A, O'Hara G, Ewer K, Lawrie A, Goodman A, Nicosia A, Folgori A, Colloca S, Cortese R, Gilbert SC, Draper SJ: Prime-boost vectored malaria vaccines: progress and prospects. Hum Vaccin 2010, 6:78-83.

50. Moorthy $\mathrm{V}$, Ballou WR: Immunological mechanisms underlying protection mediated by RTS, S: a review of the available data. Malar J 2009, 8:312.

51. Frevert $U$, Nardin E: Cellular effector mechanisms against Plasmodium liver stages. Cell Microbiol 2008, 10:1956-1967.

52. Daubersies $P$, Thomas AW, Millet $P$, Brahimi $K$, Langermans JA, Ollomo $B$, BenMohamed L, Slierendregt B, Eling W, Van Belkum A, Dubreuil G, Meis JF, Guerin-Marchand C, Cayphas S, Cohen J, Gras-Masse H, Druilhe P, Mohamed LB: Protection against Plasmodium falciparum malaria in chimpanzees by immunization with the conserved pre-erythrocytic liverstage antigen 3. Nat Med 2000, 6:1258-1263.

53. Perlaza BL, Zapata C, Valencia AZ, Hurtado S, Quintero G, Sauzet JP, Brahimi K, Blanc C, Arevalo-Herrera M, Druilhe P, Herrera S: Immunogenicity and protective efficacy of Plasmodium falciparum liver-stage Ag-3 in Aotus lemurinus griseimembra monkeys. Eur J Immunol 2003, 33:1321-1327.

54. Perlaza BL, Valencia AZ, Zapata C, Castellanos A, Sauzet JP, Blanc C, Cohen J, Arevalo-Herrera M, Corradin G, Herrera S, Druilhe P: Protection against Plasmodium falciparum challenge induced in Aotus monkeys by liver-stage antigen-3-derived long synthetic peptides. Eur J Immunol 2008, 38:2610-2615.

55. BenMohamed L, Gras-Masse H, Tartar A, Daubersies P, Brahimi K, Bossus M, Thomas A, Druilhe P: Lipopeptide immunization without adjuvant induces potent and long- lasting B, T helper, and cytotoxic T lymphocyte responses against a malaria liver stage antigen in mice and chimpanzees. Eur J Immunol 1997, 27:1242-1253.

56. Daubersies P, Ollomo B, Sauzet JP, Brahimi K, Perlaza BL, Eling W, Moukana H, Rouquet P, de Taisne C, Druilhe P: Genetic immunisation by liver stage antigen 3 protects chimpanzees against malaria despite low immune responses. PLOS ONE 2008, 3:e2659.

57. BenMohamed L, Thomas A, Druilhe P: Long-term multiepitopic cytotoxicT-lymphocyte responses induced in chimpanzees by combinations of Plasmodium falciparum liver-stage peptides and lipopeptides. Infect Immun 2004, 72:4376-4384

58. McCall MB, Sauerwein RW: Interferon-\{gamma\}-central mediator of protective immune responses against the pre-erythrocytic and blood stage of malaria. J Leukoc Biol 2010, 88:1131-1143.

59. Roestenberg M, McCall M, Hopman J, Wiersma J, Luty AJ, van Gemert GJ, van de Vegte-Bolmer M, van Schaijk B, Teelen K, Arens T, Spaarman L, de Mast Q, Roeffen W, Snounou G, Renia L, van der Ven A, Hermsen CC, Sauerwein R: Protection against a malaria challenge by sporozoite inoculation. N Engl J Med 2009, 361:468-477.

60. Keating SM, Bejon P, Berthoud T, Vuola JM, Todryk S, Webster DP, Dunachie SJ, Moorthy VS, McConkey SJ, Gilbert SC, Hill AV: Durable human memory $T$ cells quantifiable by cultured enzyme-linked immunospot assays are induced by heterologous prime boost immunization and correlate with protection against malaria. J Immunol 2005, 175:5675-5680.

61. Webster DP, Dunachie S, Vuola JM, Berthoud T, Keating S, Laidlaw SM, McConkey SJ, Poulton I, Andrews L, Andersen RF, Bejon P, Butcher G, Sinden R, Skinner MA, Gilbert SC, Hill AV: Enhanced T cell-mediated protection against malaria in human challenges by using the recombinant poxviruses FP9 and modified vaccinia virus Ankara. Proc Natl Acad Sci USA 2005, 102:4836-4841.

62. Reece $W H$, Pinder $M$, Gothard PK, Milligan P, Bojang $K$, Doherty $T$, Plebanski M, Akinwunmi P, Everaere S, Watkins KR, Voss G, Tornieporth N, Alloueche A, Greenwood BM, Kester KE, McAdam KP, Cohen J, Hill AV: A CD4(+) T-cell immune response to a conserved epitope in the circumsporozoite protein correlates with protection from natural Plasmodium falciparum infection and disease. Nat Med 2004, 10:406-410.

63. Rhodes-Feuillette A, Bellosguardo M, Druilhe P, Ballet JJ, Chousterman S, Canivet $M$, Peries J: The interferon compartment of the immune response in human malaria: II. Presence of serum-interferon gamma following the acute attack. J Interferon Res 1985, 5(1):169-178.

64. Deloron P, Chougnet C, Lepers JP, Tallet S, Coulanges P: Protective value of elevated levels of gamma interferon in serum against exoerythrocytic stages of Plasmodium falciparum. J Clin Microbiol 1991, 29(9):1757-1760.

65. Luty AJ, Bongartz M, Rezbach P, Faucher JF, Hollingdale MR, Kremsner PG: Plasmodium falciparum liver-stage antigen-1 peptide-specific interferongamma responses are not suppressed during uncomplicated malaria in African children. Eur Cytokine Netw 2001, 12:647-653.

66. Hill AV, Elvin J, Willis AC, Aidoo M, Allsopp CE, Gotch FM, Gao XM, Takiguchi M, Greenwood BM, Townsend AR, McMichael AJ, Whittle HC: Molecular analysis of the association of HLA-B53 and resistance to severe malaria. Nature 1992, 360:434-439.

67. Aidoo M, Lalvani A, Gilbert SC, Hu JT, Daubersies P, Hurt N, Whittle HC, Druihle P, Hill AV: Cytotoxic T-lymphocyte epitopes for HLA-B53 and other HLA types in the malaria vaccine candidate liver-stage antigen 3. Infect Immun 2000, 68:227-232.

68. Dieye A, Rogier C, Trape JF, Sarthou JL, Druilhe P: HLA class I-associated resistance to severe malaria: a parasitological re-assessment. Parasitol Today 1997, 13:48-49.

69. Hoffman SL, Goh LM, Luke TC, Schneider I, Le TP, Doolan DL, Sacci J, de la Vega P, Dowler M, Paul C, Gordon DM, Stoute JA, Church LW, Sedegah M, Heppner DG, Ballou WR, Richie TL: Protection of humans against malaria by immunization with radiation-attenuated Plasmodium falciparum sporozoites. J Infect Dis 2002, 185:1155-1164.

70. Sauerwein RW: Clinical malaria vaccine development. Immunol Lett 2009, 122:115-117.

71. Hollingdale MR, Appiah A, Leland P, do Rosario VE, Mazier D, Pied S, Herrington DA, Chulay JD, Ballou WR, Derks T, Yap SH, Beaudoin RL, Verhave JP: Activity of human volunteer sera to candidate Plasmodium falciparum circumsporozoite protein vaccines in the inhibition of sporozoite invasion assay of human hepatoma cells and hepatocytes. Trans R Soc Trop Med Hyg 1990, 84:325-329.

72. Mazier D, Mellouk S, Beaudoin RL, Texier B, Druilhe P, Hockmeyer W, Trosper P, Paul Y, Charoenvit Y, Young J, Miltgen F, Chedid L, Chigot JP, Galley B, Brandicourt O, Gentilini M: Effect of antibodies to recombinant and synthetic peptides on Plasmodium falciparum sporozoites in vitro. Science 1986, 231:156-159.

73. Pasquetto V, Fidock DA, Gras H, Badell E, Eling W, Ballou WR, Belghiti J, Tartar A, Druilhe P: Plasmodium falciparum sporozoite invasion is inhibited by naturally acquired or experimentally induced polyclonal antibodies to the STARP antigen. Eur J Immunol 1997, 27:2502-2513.

74. Brahimi K, Badell E, Sauzet JP, BenMohamed L, Daubersies P, GuerinMarchand C, Snounou G, Druilhe P: Human antibodies against Plasmodium falciparum liver-stage antigen 3 cross-react with Plasmodium yoelii preerythrocytic-stage epitopes and inhibit sporozoite invasion in vitro and in vivo. Infect Immun 2001, 69:3845-3852.

75. Muller HM, Scarselli E, Crisanti A: Thrombospondin related anonymous protein (TRAP) of Plasmodium falciparum in parasite-host cell interactions. Parassitologia 1993, 35(Suppl):69-72.

76. Silvie O, Franetich JF, Charrin S, Mueller MS, Siau A, Bodescot M, Rubinstein E, Hannoun L, Charoenvit Y, Kocken CH, Thomas AW, Van Gemert GJ, Sauerwein RW, Blackman MJ, Anders RF, Pluschke G, Mazier D: A 
role for apical membrane antigen 1 during invasion of hepatocytes by Plasmodium falciparum sporozoites. J Biol Chem 2004, 279:9490-9496.

77. Potocnjak P, Yoshida N, Nussenzweig RS, Nussenzweig V: Monovalent fragments (Fab) of monoclonal antibodies to a sporozoite surface antigen (Pb44) protect mice against malarial infection. J Exp Med 1980, 151:1504-1513.

78. Yoshida N, Nussenzweig RS, Potocnjak P, Nussenzweig V, Aikawa M: Hybridoma produces protective antibodies directed against the sporozoite stage of malaria parasite. Science 1980, 207:71-73.

79. Doolan DL, Sedegah M, Hedstrom RC, Hobart P, Charoenvit Y, Hoffman SL: Circumventing genetic restriction of protection against malaria with multigene DNA immunization: CD8+ cell-, interferon gamma-, and nitric oxide-dependent immunity. J Exp Med 1996, 183:1739-1746.

80. Mellouk S, Green SJ, Nacy CA, Hoffman SL: IFN-gamma inhibits development of Plasmodium berghei exoerythrocytic stages in hepatocytes by an L-arginine-dependent effector mechanism. J Immunol 1991, 146:3971-3976.

doi:10.1186/1475-2875-10-27

Cite this article as: Perlaza et al: Interferon- $\gamma$, a valuable surrogate marker of Plasmodium falciparum pre-erythrocytic stages protective immunity. Malaria Journal 2011 10:27.

\section{Submit your next manuscript to BioMed Central and take full advantage of:}

- Convenient online submission

- Thorough peer review

- No space constraints or color figure charges

- Immediate publication on acceptance

- Inclusion in PubMed, CAS, Scopus and Google Scholar

- Research which is freely available for redistribution

Submit your manuscript at www.biomedcentral.com/submit 